\title{
"THE NINETEEN-SEVENTIES": SUMMARY FOR PRESENTATION TO THE ACCIDENT COMPENSATION SYMPOSIUM
}

\author{
Right Hon Sir Geoffrey Palmer
}

After the Woodhouse Commission delivered its Report, more conventional political considerations surrounded its progress toward legislative enactment. The stunning replacement of common law stood at the core of reform, but the nature of the alternative scheme remained open to debate. It took six years, multiple cabinet reports and committee procedures, and political compromises amidst a change in government before the legislation took effect in 1974. In this article, one of the central players from this period reflects on the political environment leading up to enactment, and describes how the ultimate legislation modified aspects of the original Woodhouse vision.

\section{INTRODUCTION}

The purpose of this paper is to offer some observations on the New Zealand accident compensation system from one who was involved in its design at the beginning. The issues now look fundamentally different from the way they looked then. It is important to try and avoid making judgements based on the advantage of hindsight. But it is possible to isolate a number of issues that still seem of importance to the contemporary scheme, although many others in the seventies proved to be ephemeral.

The legislative history of accident compensation falls neatly into decades:

1. Accident Compensation Act 1972

2. Accident Compensation Act 1982

* Partner, Chen Palmer and Partners, Barristers and Solicitors, Public Law Specialists, Wellington. He was retained to draft the document "Personal Injury - A Commentary on the Report of the Royal Commission of Inquiry into Compensation for Personal Injury in New Zealand" [1969] AJHR H-50. 
3. Accident Rehabilitation and Compensation Insurance Act 1992

4. Injury Prevention, Rehabilitation, and Compensation Act 2001.

Having started life as a measure, the principles of which were broadly supported by both main political parties in New Zealand - National and Labour - the issues over the decades became progressively more controversial in political terms. That remains the situation today. Surprisingly, the issue that divides the parties now is not one that goes to the fundamental nature of the reform.

The fundamental nature of the reform was to replace the common law as a means of compensating for personal injury and put a 24 -hour-no-fault scheme in its place. That purpose was accomplished. It remains the single most important feature of the scheme. The New Zealand scheme remains and has remained throughout its history, despite the chequered nature of the legislative changes within New Zealand, the most comprehensive reform of the tort system in the common law world.

It is a matter of some curiosity that the most controversial aspect of the scheme in New Zealand in 2002 is the question of whether it should be administered by private enterprise or whether it should be run by a State monopoly. That is a surprising issue to emerge, given the logic of the original Woodhouse proposals. Those proposals were based on the undoubted inefficiency of the old common law systems backed by compulsory insurance. This system delivered some benefits to a few but at an extraordinarily high cost. Recall that the Royal Commission found in 1967 that the systems of common law and workers' compensation backed by compulsory but privately administered insurance was cumbersome and inefficient. The extravagance was demonstrable. It absorbed for administration and other charges "as much as $\$ 40$ for every $\$ 60$ paid over to successful claimants". ${ }^{1}$ In recent years it has cost about 7 cents for ACC to deliver a dollar in benefits.

It strikes me as interesting that more than a generation later policy-makers would argue, with at least some superficial plausibility, that private insurance company administration, which would be competitive, would in fact be superior to the State running a comprehensive scheme. The manner in which the private insurance companies operated under the old systems was wasteful. It was remarkable that the issue of private insurance company involvement was raised again and was for some period legislated for.

It is worth rehearsing the nature of the attack on the common law on which the Woodhouse Reports in both Australia and New Zealand were based. Those arguments carried the day in New Zealand and nowhere else as far as a comprehensive replacement of the common law remedy is concerned. The arguments were as follows:

1 New Zealand Royal Commission of Inquiry into Compensation for Personal Injury Compensation for Personal Injury in New Zealand: Report of the Royal Commission of Inquiry (Government Printer, Wellington, 1967) para 485(4) [Woodhouse Report]. 
- The failure of the common law to compensate large numbers of accident victims;

- The waste involved in the system in that much of the money was chewed up in legal and administrative expenses;

- The long delays in delivering benefits to those who secured them;

- That personal blameworthiness was not the real rationale for the law because negligence law required individuals to meet the community average standard;

- $\quad$ "Reprehensible conduct can be followed by feather blows while a moment's inadvertence could call down the heavens" as the Woodhouse Report put it; ${ }^{2}$

- That liability insurance had blunted or removed the deterrent effect of tort law;

- That an assessment of damages in one lump sum involved guesswork and speculation and tended to over-compensate less serious injuries;

- That the process of adjudication was a lottery and impeded the rehabilitation of injured people, and there were strong incentives to maximise misery; and

- Accident prevention was impeded by the system.

The great attraction of the original proposals and the one that was finally, after a stern struggle, accepted by the policy-making and political establishment in New Zealand in the late sixties and early seventies was that you could have a much better compensation system offering 24-hour coverage on a no fault basis for the same money as was being spent on the old systems. To this logic, the destruction of the common law was fundamental. It was the only way to free up and liberate the money to finance the new system.

It is important to remember that the divisions between National and Labour in the seventies were slight. The National Party legislated the scheme first in 1972. But it did so without covering non-earners. In the 1972 election the Labour Party pledged to extend the scheme to non-earners who were injured, following the original Royal Commission's recommendation. That was a relatively easy thing to achieve since the scheme had not yet started to operate.

Just as New Zealand forgot over a period of more than 25 years why it had originally passed the accident compensation legislation, there is a danger it may forget in the future the manifest social injustices visited upon injured people by the common law. We are fortunate to have been spared some of the difficulties that can occur in this area.

One only has to look at the current insurance crisis afflicting the tort system in Australia to be aware of the great advantages New Zealand has in being spared the vagaries of the tort system

2 Woodhouse Report, above. 
backed by insurance. ${ }^{3}$ Thus the conclusion I reach in this part of the paper is that New Zealand got something right. To get rid of the common law virtually completely was the right approach and that should never be forgotten. However, there are a number of loose ends still in the New Zealand situation where that objective should be rigorously examined and the legislation readdressed. ${ }^{4}$

The second major point that comes from the seventies is that the Woodhouse Report was never fully enacted. Its primary recommendation relating to the common law was enacted to a large degree, but a great many of the other recommendations were not followed. It may well be the case that things would have developed in a more satisfactory fashion if they had been. The explanation for this is complicated and I will not address it at length here. The full story is to be found in a book I published in $1979 .^{5}$

The explanation for these changes needs to be understood. The Woodhouse Report was given to a National government. The scheme was radical and far-reaching. It required a lot of political digestion on the part of the National Party caucus to embrace the report and, as indicated earlier, in the end it was only able to go as far as covering all earners excluding the non-earners. The methods by which the matter was dealt with by the government of the day included the commissioning of a government White Paper on the subject. ${ }^{6}$ That was followed by the select committee chaired by the Hon George Gair that hammered out the policy that was finally accepted by the National Party.

There was a great deal of political manoeuvring within the National Party government, and particularly the caucus, to arrive at a conclusion as bold as the one that was arrived at. Furthermore, the legislation itself, when it was introduced, was referred to another select committee chaired by the Hon Colin McLachlan. The policies were further fine-tuned and amended there. These processes were backed by a well-resourced and able inter-departmental committee.

But the important point for present purposes is that the fate of many of the Woodhouse Report recommendations was that they were to be either modified, amended or abandoned. At least 36 major issues existed upon which decisions had to be taken in order to arrive at a coherent policy. Each decision involved the weighing of several possibilities and the rejection of all but one. The essence of the Woodhouse style of reform is that policy factors are arranged in a complex sort of

3 "Uncovered and Suffering for It" (17 March 2002) Sunday Age, 6; "States' Tort Reform Packages Poles Apart" (10 May 2002) Australian Financial Review; "Insurance in Crisis" (30 May 2002) Australian Financial Review 9; and see also (24 June 2002) Australian Financial Review 47.

4 For example, nervous shock cases. For more on this see Geoffrey Palmer "The Design of Compensation Systems: Tort Principles Rule, OK?" (1995) 29 Valparaiso Law Review 1115.

5 Geoffrey Palmer Compensation for Incapacity - A Study of Law and Social Change in New Zealand and Australia (Oxford University Press, Wellington, 1979).

6 "Personal Injury: A Commentary on the Report of the Royal Commission of Inquiry into Compensation for Personal Injury in New Zealand" [1969] IV AJHR 1150. 
equilibrium. The balance between the various features of a scheme of this comprehensive nature is such that the right mix is not easy to achieve. The major questions upon which the Woodhouse policy was rejected concerned the following:

- $\quad$ Administration;

- $\quad$ The appeals mechanism;

- $\quad$ Limitations on short-term compensation;

- Compensation for permanent partial incapacity - particularly the opposition in the Woodhouse Report to lump sum compensation;

- $\quad$ The method of raising levies - especially differential rating and penalties;

- Widow's benefits;

- A notional earnings floor for non-earners. ${ }^{7}$

In order to show the nature of the changes that were made to the Royal Commission's recommendations, I set out a table that originally appeared in my 1979 book: ${ }^{8}$

\begin{tabular}{|c|c|c|}
\hline $\begin{array}{l}\text { Appendix I } \\
\text { Reference }\end{array}$ & Issue & $\begin{array}{l}\text { Sources of Policy that Prevailed Contrary to } \\
\text { Royal Commission Recommendations }\end{array}$ \\
\hline 3 & Demarcation & $\begin{array}{l}\text { Officials and accident commission endorsed by } \\
1974 \text { select committee }\end{array}$ \\
\hline 10 & Compensation minimal & Gair Committee and officials \\
\hline 11 & Age limits & Commentary and Gair Committee \\
\hline 12 & $\begin{array}{l}\text { Limitations on short term } \\
\text { compensation }- \text { first week etc }\end{array}$ & Commentary, Gair Committee, and officials \\
\hline 14 & $\begin{array}{l}\text { Permanent partial incapacity and non- } \\
\text { economic loss }\end{array}$ & Commentary, Gair Committee and officials \\
\hline 16 & Loss of potential earnings & Officials \\
\hline 17 & Non-earners & Gair Committee and officials \\
\hline 19 & Double payments & Officials \\
\hline 21 & Pecuniary loss & Gair Committee \\
\hline
\end{tabular}

7 For a further discussion of this see Geoffrey Palmer "What happened to the Woodhouse Report?" [1981] NZLJ 561.

8 Geoffrey Palmer Compensation for Incapacity - A Study of Law and Social Change in New Zealand and Australia (Oxford University Press, Wellington, 1979). 


\begin{tabular}{|c|l|l|}
\hline $\begin{array}{c}\text { Appendix I } \\
\text { Reference }\end{array}$ & \multicolumn{1}{|c|}{ Issue } & $\begin{array}{c}\text { Sources of Policy that Prevailed Contrary to } \\
\text { Royal Commission Recommendations }\end{array}$ \\
\hline 24 & Widows compensation & Commentary and Gair Committee \\
\hline 28 & Disqualifications & Officials \\
\hline 29 & Incapacity occurring overseas & Officials \\
\hline 30 & Visitors to New Zealand & Commentary and Gair Committee \\
\hline 31 & Administration & Commentary, Gair Committee, and officials \\
\hline
\end{tabular}

Looking at these matters now, it becomes plain that the relatively low levels of compensation that were paid to people who were off work for a short period under the Woodhouse Report would have made the profile of the scheme quite different had those recommendations been enacted.

The first point was that there was no compensation to be paid for the first week. The second point is that the Royal Commission recommended a very low limit flat rate of weekly compensation for the first four weeks of incapacity, where the incapacity lasted not longer than eight weeks. The third point was that the Royal Commission was not in favour of lump sum compensation. Compensation for dignitary harm was built into the awards for permanent incapacity. These recommendations, of course, ran into strong opposition from the trade unions at the select committee hearings, but the history of accident compensation in New Zealand would have been very different had the original recommendations in these three matters been followed.

The Woodhouse Report did not see merit in the 'allocation of costs' economic arguments so popular in the law and economics literature about the time the recommendations were made. It recommended instead that there ought not to be differential premiums or levies. As a recent graduate of the University of Chicago Law School when I wrote the government white paper, I felt this approach of the Royal Commission may have been misguided.

I tended to start out as a believer in the principles of general deterrence that Guido Calabresi set out in his seminal book The Costs of Accidents. ${ }^{9}$ I felt that the law and economics analysis concerning general deterrence, even at the early stages of the development of the policy, had some validity. But when efforts were made to try and make it work, it turned out that the data had not been generated in New Zealand and did not exist. The administrative problems associated with segmenting the injuries down to their causes and internalising them to particular industries was such a hard administrative job that designing the statute or the regulations became problematic.

9 Guido Calabresi The Cost of Accidents - A Legal and Economic Analysis (Yale University Press, New Haven, 1970). This book was preceded by a number of articles in law reviews in which the issues were debated and these were cited in the 1969 commentary. 
Thus, after many years of having some belief in this system and looking at it in a number of jurisdictions, I turned into a sceptic about whether it could be achieved. There were and are a whole range of problems. One of these problems is the question of the importance of the costs of accidents, compared with other costs that a firm may have. Are they enough to make a difference to the behaviour of the firm? Then there are the problems about what is a cost of what. That was wonderfully demonstrated in the New Zealand scheme when all the motorcyclists (who had had their levy go up because of the Accident Compensation Corporation paying out a lot of money to injured motorcyclists) said, in effect as they demonstrated by driving their motorcycles around Parliament with the silencers off, "if it was not for motorcars motorcycles would be very safe". Deterrence in relation to non-work accidents is even more difficult. And when one comes to factor sporting injuries into the mix, the methods of administration and collection become difficult.

There are severe problems with the law and economics approach in terms of the allocation of accident costs at the detailed level of implementation. I have never seen any practical work about how to do it. I have never seen a scheme for the achievement of general deterrence worked out effectively statistically and rigorously that would be capable of being implemented.

The best research on the subject that I have seen comes from Canada and it indicates that there is not any unambiguous evidence that the tort system has any significant deterrent effect, whether directly or within the more sophisticated law and economics analysis. ${ }^{10}$

Another major point from the seventies is the nature of the administration of the accident compensation system in New Zealand. You will recall that it started life as the Accident Compensation Commission. Then it became, under the 1982 Act, the Accident Compensation Corporation managed by a board. The purpose of the 1982 policy appears to have been to try and insert a degree of stakeholder participation into the policy setting. It was also aimed at bringing a more businesslike set of management processes to the bureaucracy. It became in 1992 a rather different organisation and in time developed a practice that permitted a measure of privatisation subsequently enacted by the National government.

The original Woodhouse Report recommendation in this connection deserves to be considered as well. The Royal Commission envisaged that its scheme would be brought to life and set upon its course by an independent authority. But that authority should operate within the general responsibility of the Minister of Social Security and be attached to his department for administrative purposes, the report said.

10 Don Dewees and Michael Trebilcock "The Efficacy of the Tort System and its Alternatives: A Review of Empirical Evidence" (1992) 30 Osgood Hall LJ 57; Don Dewees, David Duff and Michael Trebilcock, Exploring the Domain of Accident Law - Taking the Facts Seriously (Oxford University Press, Oxford, 1996). 
That recommendation was not followed. Many of the policy difficulties that have occurred in New Zealand since are, in my view, traceable to this decision. By setting up an independent Accident Compensation Commission of three Commissioners in the first instance and later a Corporation, neither of which were organised as part of the core State Services in New Zealand, the accident compensation system became something of a policy orphan within government. The Department of Labour maintained responsibility for policy development but, in practice, this was developed by the Commission and later the Corporation itself. There is now a small coterie of officials in the Department that provide advice. The policy-generating capacity of the ACC turned out to be somewhat haphazard and unsatisfactory. Further, the organisation was left aside from deliberations within the core government departments for long periods of time, with the result that there was no integration of policy advice within the workings of central government. There is currently a Minister for Accident Insurance.

Why the Department of Labour retains responsibility for this area is hard to say and really the only reason is historical. Change needs to be considered and I would still feel more comfortable if the accident compensation system was administered through a Department of State. I think over time this would ensure that the policy-making procedures in relation to it would work better than they do now. I do not have the space in this paper to develop that thesis, but it is a matter upon which I have given some thought over the years. I am in some doubt that the current arrangements are satisfactory.

The last matter upon which I wish to dwell as an insight from the seventies is the unresolved issue of the relationship of accident compensation to the rest of the income-maintenance system. The person who is injured and the person who suffers from disease should, as a matter of social equity, be treated the same. But to pay victims of accidents earning-related benefits of a generous character and flat rate income-tested benefits to those who are sick is not an easy social distinction to draw.

I note that the Royal Commission on Social Policy could find no justification for the stark inequality caused by society's response to the injured compared with the sick and disabled. They found it was an unfairness that could not stand. This is what they said in $1988:^{11}$

Sickness, and injury and disability are hazards of life to which all are potentially subject. It has been increasingly accepted that the community should bear a share of the costs of relieving some of the burden of individual victims and their families. But developments have occurred in a piecemeal fashion and on any application of the criteria of equity and efficiency present arrangements fail badly. A person struck down by disease may suffer the same kinds of economic and social loss as are sustained by a person struck down by a car, yet the community response as measured by the community-funded support is markedly different.

11 Royal Commission on Social Policy "Future Directions" (Government Printer, Wellington, 1988) 757. 
The recommendations of this Royal Commission were not taken up. The Law Commission's report on accident compensation came out about six weeks later and had a different line. Efforts were made in the dying days of the Fourth Labour Government to redress this problem, but they failed.

Somehow or other, policy-makers have been able to avoid engaging with the problem ever since but, in my view, it is necessary to do so. However, the enactment of the new scheme with generous lump sums will make that task all the more difficult. Of course reconstruction and integration of income-maintenance in New Zealand then and now is singularly difficult.

Not long after the accident compensation scheme commenced, an enormous change was made to New Zealand's retirement scheme called national superannuation. Funded out of taxation, it provided generous benefits for everyone over 60 years of age, free of any income or asset test. This result of the 1975 general election is still part of our political debate today. And securing consensus and agreement on retirement income policy has been a problem that has beset the New Zealand political system from 1975 onwards. Even today it is a live issue in the election campaign.

\section{CONCLUSION}

The Woodhouse Report was a warm-hearted and humane document. It took an optimistic view of human nature. The basic idea was that those in distress should be helped and that the wellbeing of each was of concern to all. The central core of both Woodhouse Reports was to get rid of the common law and substitute something better in its place. In that aim the Woodhouse reforms undoubtedly succeeded. And the wide measure of agreement about the fundamental principle of nofault compensation in New Zealand now seems too well established to be removed. We will not see any widespread return to the common law action for personal injury damages in New Zealand.

But there remain difficult areas of policy and administration created by the scheme. In particular its relationship to the wider issues of income-maintenance remain to be addressed.

Viewed in its own terms as essentially a legal reform, accident compensation must be regarded as a success. Nowhere, not in the United Kingdom, the United States, Canada or Australia, or any other common law country, has such a comprehensive reform of the tort system been undertaken or endured for so long. Sometimes in New Zealand we get things right. 
